\title{
Application of Stable Isotope Ratio Analysis for Origin Authentication of Pork
}

\author{
Kyong Su Kim*, Jae Sung Kim, In Min Hwang, In Seon Jeong, Naeem Khan, \\ Sun Im Lee ${ }^{1}$, Dong Bok Jeon ${ }^{1}$, Yang Hoon Song ${ }^{2}$, and Kwan Suk Kim ${ }^{2}$ \\ Department of Food and Nutrition, Chosun University, Gwangju 501-759, Korea \\ ${ }^{1}$ Department of International Tea Culture, Chosun University, Gwangju 501-759, Korea \\ ${ }^{2}$ Life and Environment Sciences, Chungbuk University, Cheongju 361-763, Korea
}

\begin{abstract}
Origin authenticity of the animals used as food has always been a major concern to consumers around the world. In the past twenty years, a stable isotope ratio has been used for origin authentication. In this study, pork samples, both local and imported, were collected from the major markets from all around South Korea and analyzed for stable isotope ratios of nitrogen $\left(\delta^{15} \mathrm{~N} \%\right)$ and carbon $\left(\delta^{13} \mathrm{C} \%\right.$ ), using Isotope Ratio Mass Spectrometry (IR-MS). A total of 599 samples with 335 Korean and 264 imported from 13 countries within America and Europe were investigated in accordance to the standard established methods for isotope ratio analysis. The results showed a significant variation related to the origin of the samples, explaining the difference in the feeding styles of the pork in each country. The stable isotope ratio values of carbon $\left(\delta^{13} \mathrm{C} \%\right)$ were found in the decreasing order of: America $(-15.55 \pm 1.01 \%$ ) $>$ Korea $(-19.62 \pm 0.89 \%$ o $)>$ Europe $(-24.79 \pm 1.35 \%$ ). Canada was having $\delta^{13} \mathrm{C}$ ratio of $-22.87 \pm 0.92 \%$, which is very low in the region of America and very close to Europe (-23.78 to $27.17 \%$ ). For nitrogen $\delta^{15} \mathrm{~N} \%$ the order was: America $(4.92 \pm 0.71 \%$ ) $>$ Europe $(4.54 \pm 0.66 \%$ ) $>$ Korea $(3.69 \pm 0.54 \%$ ), with a slight variation among countries in each region studied. From the results it was concluded that the stable isotope ratio of the pork samples from different countries provide enough information about the origin and is therefore a potential tool which can be employed for origin authentication.
\end{abstract}

Key words: origin authentication, IR-MS, stable isotopes ratio, pork, Korea

\section{Introduction}

Under the umbrella of World Trade Organization (WTO), the trade volume of food and merchandise are increasing day by day. Each country in the world has distinct latitude and climatic conditions and therefore having special qualitative and quantitative characteristics in their food and food products. Accordingly, consumers always demand for reliable information about the food origin which is an important part in their food selection (Boner and Forstel, 2004; Hargin, 1996). However, presently some of the food suppliers do not fully describe the origin of food animals and other stuffs; even on wide spread transportation, for allied high profits. In European Union, each county have made food name chimes, by various

*Corresponding author: Kyong Su Kim, Department of Food and Nutrition, Chosun University, Gwangju 501-759, Korea. Tel: 82-62-230-7724, Fax: 82-62-224-8880, E-mail: kskim@ chosun.ac.kr labeling systems, for the protection of food origin on geographical basis (EEC, 1992).

Organic matter analysis to determine the food origin, involve application of techniques like near-infrared spectroscopy (Lee et al., 2006), x-ray fluorescence spectrometry (Jeong and Lee, 2008), electronic nose (Lee, 2006), capillary electrophoresis (Kim et al., 2003) and nuclear magnetic resonance (NMR) (Kim et al., 2009). Recently mineral analysis through inductively coupled plasma mass spectrometry (ICP-MS) (Kang et al., 2001), along with genetic methods (Choi et al., 2004), and isotope ratio analysis (Jardine et al., 2003; Peterson and Fry, 1987) have also been tried for origin authentication. Out of these methods, isotope ratio analysis, for determination of the food origin, has been proved to be the most useful method and many studies are currently underway around the world.

Isotopes of an element have different number of neutrons and they behave differently in phenomena such as metabolism, vaporization and natural circulation and by 
examining the stable isotope ratio of the area's environment and the origin can be inferred (Camin et al., 2007; Peterson and Fry, 1987). Stable isotopes are those isotopes of an element that do not decay through radioactive processes over time. Several elements have more than one stable isotopes in nature which include hydrogen $\left(\mathrm{H}^{2}\right.$, $\left.\mathrm{H}^{1}\right)$, boron $\left(\mathrm{B}^{11}, \mathrm{~B}^{10}\right)$, carbon $\left(\mathrm{C}^{13}, \mathrm{C}^{12}\right)$, nitrogen $\left(\mathrm{N}^{15}\right.$, $\left.\mathrm{N}^{14}\right)$, oxygen $\left(\mathrm{O}^{18}, \mathrm{O}^{16}\right)$, sulfur $\left(\mathrm{S}^{34}, \mathrm{~S}^{32}\right)$, strontium $\left(\mathrm{Sr}^{87}\right.$, $\left.\mathrm{Sr}^{86}\right)$ and lead $\left(\mathrm{Pb}^{207}, \mathrm{~Pb}^{206}\right)$ (Ghidini et al., 2006). A significant fraction of stable isotopes always occur in food and food products and therefore isotope ratio analysis has been described as a useful tool of origin authenticity for the last more than 20 years (Simon et al., 2005). Stable isotope ratio of hydrogen $\left(\delta^{2} \mathrm{H}\right)$ and oxygen $\left(\delta^{18} \mathrm{O}\right)$ provides information about climatic conditions of the region and that of sulfur $\left(\delta^{34} \mathrm{~S}\right)$ provides information about surface geology of the area (Balling and Rossmann, 2004). The carbon $\left(\delta^{13} \mathrm{C}\right)$ value tells about feeding habits, specific to a region (Kim et al., 2003; Kim et al., 2009; Lim et al., 2008) and nitrogen $\left(\delta^{15} \mathrm{~N}\right)$ value explains about plants, available nitrogen in the soil and atmosphere which are also dependent upon geographical and climatic conditions (Anklam, 1998; Yuta et al., 2012).

Origin authentication is associated mostly to meats because of their usual long distance between producers and consumers and often resulting in crisis of origin (Jeong and Lee, 2008). The meat concerning several studies have been focusing on the distinction of stable isotope $\left({ }^{13} \mathrm{C},{ }^{15} \mathrm{~N},{ }^{18} \mathrm{O},{ }^{34} \mathrm{~S},{ }^{87} \mathrm{Sr}\right)$ ratio analysis (Camin et al., 2007; Hegerding et al., 2002). Stable isotope ratio analysis has been used to determine the origin on wine (Day et al., 1995), milk (Renou et al., 2004), honey (Anklam, 1998), and butter (Balling and Rossmann, 2004), and cattle beef (Yuta et al., 2012).

The present study was aimed to analyze the stable isotope ratios of carbon $\left(\delta^{13} \mathrm{C}\right)$ and nitrogen $\left(\delta^{15} \mathrm{~N}\right)$ in pork samples of various countries available in South Korean markets to evaluate differentiation between animal feeding and geographical origin and to apply for authentication of origin.

\section{Materials and Methods}

\section{Samples collection}

A total of 599 pork samples of 14 countries from South Korea, Europe and America were collected from all around Korean markets. These included 335 local and 264 intentionally imported varieties to South Korea as shown in Table 1. All these samples were sourced through the
National Agricultural Products Quality Management Service, Republic of Korea. Only muscle tissues were collected directly from producers and to analyzed for stable isotope ratios of carbon $\left(\delta^{13} \mathrm{C}\right)$ and nitrogen $\left(\delta^{15} \mathrm{~N}\right)$, using EA-IR/MS.

\section{Samples preparation}

Meat samples were cut into thin slices and removed the fat contents. Then $10 \mathrm{~g}$ of each sample was added with $100 \mathrm{~mL}$ toluene and lypholized for $2 \mathrm{~h}$ at atmospheric pressure, using azeotropic distillation apparatus to obtain pure protein and remove fat and water. The purified samples were then washed with fresh toluene and then used a rotary evaporation system (Rotavapor R-215, BUCHI, Switzerland) to separate solvent. It was then dried for $5 \mathrm{~h}$ at $80^{\circ} \mathrm{C}$ in oven (HB-502M, Han Back, Korea). The samples were then homogenized and stored at $-20^{\circ} \mathrm{C}$, prior to analysis.

\section{Isotope ratios determination}

The samples were analyzed by using continuous flowthrough inlet system-isotope ratio mass spectrometry (Choy et al., 2009). The elemental analyzer (EA 3000, $\mathrm{EV}$, Italy) was connected with a continuous flow-through inlet system-isotope ratio mass spectrometer (CF isotope ratio mass spectrometer, Isoprime, GV Instruments, UK).

First the instrument was calibrated, using sucrose $(\mathrm{CH}-$ 6 , IAEA) $\delta^{13} \mathrm{C}=-10.4 \pm 0.2 \%$ and ammonium sulfate (N1, IAEA) $\delta^{15} \mathrm{~N}=+0.4 \pm 0.2 \%$, as internal standards for $\delta^{13} \mathrm{C}$ and $\delta^{15} \mathrm{~N}$, respectively. The prepared samples $(0.1-1.0$ $\mathrm{mg}$ ) wrapped in tin capsules for oxidation-reduction, at $1,050^{\circ} \mathrm{C}$ and $650^{\circ} \mathrm{C}$ for perfect combustion organic matter in the element analyzer.

The combustion tube was filled with tungsten oxide and cobalt (II/III) oxide to support the oxidation and second tube filled with copper for reduction. The gases $\left(\mathrm{CO}_{2}\right.$ and $\mathrm{N}_{2}$ ) were separated by a gas chromatographic column and introduced into the CF-IR/MS. The detail condition of EA-IR/MS for analyzing $\delta^{13} \mathrm{C}$ and $\delta^{15} \mathrm{~N}$ are presented in Table 2. Tin capsule for analyzing isotope ratio were bought from Euro Vector (Milan, Itary). The degree of purity for carrier gas $(\mathrm{He})$ and reference gases $\left(\mathrm{N}_{2}\right.$ and $\mathrm{CO}_{2}$ ) were over $99.999 \%$. Isotope ratio of carbon and nitrogen were converted into $\delta \%$, according to the following equation.

$$
\delta \text { value }(\%)=\left(\frac{\mathrm{R}_{\text {sample }}}{\mathrm{R}_{\text {standard }}}-1\right) \times 1,000
$$

$\delta$-value is the isotope ratio of the sample expressed in 
delta unit (\%) relative to the reference material. $\mathrm{R}_{\text {sample }}$ is the isotope ratio of measured sample in particular ${ }^{13} \mathrm{C} /{ }^{12} \mathrm{C}$ and ${ }^{15} \mathrm{~N} /{ }^{14} \mathrm{~N}$ and $\mathrm{R}_{\text {standard }}\left({ }^{13} \mathrm{C} /{ }^{12} \mathrm{C}\right.$ and $\left.{ }^{15} \mathrm{~N} /{ }^{14} \mathrm{~N}\right)$ is the isotope ratio of International standard material: V-PDB (Vienna Pee Dee Belemnite) for $\delta^{13} \mathrm{C}$ and atmospheric $\mathrm{N}_{2}$ for $\delta^{15} \mathrm{~N}$.

\section{Statistical analysis}

The data was analyzed using one-way analysis of variance (ANOVA) to examine statistical significance of the difference in the mean concentrations of $\delta^{13} \mathrm{C}$ and $\delta^{15} \mathrm{~N}$ among the countries studied. A probability level of $p=$ 0.05 was considered statistically significant. The SPSS system for windows of V18.0 software was employed for statistically analysis (SPSS Inc., USA).

Table 1. Stable isotope ratios carbon $\left(\delta^{13} \mathrm{C} \%\right)$ and nitrogen $\left(\delta^{15} \mathrm{~N} \%\right)$ composition of the pork defatted dry mass (DDM) protein from different geographical regions

\begin{tabular}{|c|c|c|c|}
\hline \multirow{2}{*}{ Region Country } & \multirow{2}{*}{$\begin{array}{c}\text { Number of } \\
\text { Samples }\end{array}$} & \multirow{2}{*}{$\frac{\delta^{13} \mathrm{C}[\% 0]_{\mathrm{v}-\mathrm{PDB}}}{\text { Mean } \pm \mathrm{SD}^{1)}}$} & \multirow{2}{*}{$\begin{array}{c}\delta^{15} \mathrm{~N}[\% 0]_{\mathrm{AIR}} \\
\text { Mean } \pm \text { SD }\end{array}$} \\
\hline & & & \\
\hline South Korea & 335 & $-19.62^{\mathrm{c} 2)} \pm 0.89$ & $3.69^{\mathrm{ab}} \pm 0.54$ \\
\hline \multirow{4}{*}{ America } & 7 & $-22.87^{\mathrm{d}} \pm 0.92$ & $5.65^{\mathrm{e}} \pm 0.53$ \\
\hline & 30 & $-14.78^{\mathrm{a}} \pm 1.34$ & $5.42^{\mathrm{de}} \pm 0.58$ \\
\hline & 7 & $-14.81^{\mathrm{a}} \pm 0.46$ & $4.81^{\mathrm{cd}} \pm 0.56$ \\
\hline & 74 & $-15.93^{\mathrm{ab}} \pm 0.63$ & $4.72^{\mathrm{cd}} \pm 0.67$ \\
\hline Austr & 20 & $-24.20^{\mathrm{ef}} \pm 1.27$ & $4.42^{\mathrm{bc}} \pm 0.51$ \\
\hline Netherland & 30 & $-25.57^{f} \pm 1.20$ & $4.58^{\mathrm{c}} \pm 0.47$ \\
\hline Denmark & 10 & $-25.24^{\mathrm{f}} \pm 0.22$ & $3.62^{\mathrm{a}} \pm 0.15$ \\
\hline France & 22 & $-24.35^{\mathrm{ef}} \pm 1.05$ & $4.96^{\mathrm{cde}} \pm 0.50$ \\
\hline Europe Belgium & 35 & $-24.80^{\mathrm{ef}} \pm 1.33$ & $4.46^{\mathrm{c}} \pm 0.73$ \\
\hline Finland & 3 & $-27.17^{\mathrm{ef}} \pm 0.52$ & $5.73^{\mathrm{e}} \pm 0.31$ \\
\hline Poland & 15 & $-24.77^{\mathrm{ef}} \pm 1.52$ & $4.53^{\mathrm{c}} \pm 0.85$ \\
\hline Hungary & 6 & $-23.78^{\text {de }} \pm 1.48$ & $4.42^{\mathrm{bc}} \pm 0.58$ \\
\hline Spain & 5 & $-23.44^{\mathrm{de}} \pm 1.09$ & $4.68^{\mathrm{cd}} \pm 0.26$ \\
\hline
\end{tabular}

${ }^{1)}$ Mean \pm standard deviation

2)a-g Values with different letters within a column differ significantly $(p=0.05)$.

Table 2. Operating conditions of EA-IR/MS for analyzing $\delta^{13} \mathrm{C} \%$ and $\delta^{15} \mathrm{~N} \%$ values of the pork defatted dry mass (DDM) protein from different geographical regions

\begin{tabular}{ll}
\hline \hline \multicolumn{1}{c}{ Parameters } & \multicolumn{1}{c}{ Operating conditions } \\
\hline Combustion furnace & $1,050^{\circ} \mathrm{C}$ \\
Reduction furnace & $650^{\circ} \mathrm{C}$ \\
GC packed column oven & $115^{\circ} \mathrm{C}$ \\
Reference capillary column & $\mathrm{L}=1.5 \mathrm{~m}$, I.D.(f) $=100 \mathrm{~mm}$ \\
Sample capillary column & $\mathrm{L}=2.5 \mathrm{~m}, \mathrm{I} . \mathrm{D} .(\mathrm{f})=75 \mathrm{~mm}$ \\
Run time & $385 \mathrm{sec}$ \\
He carrier flow & $115 \mathrm{~mL} / \mathrm{min}$ \\
\hline
\end{tabular}

\section{Results}

The stable isotope ratio measurements of carbon $\left(\delta^{13} \mathrm{C}\right)$ and nitrogen $\left(\delta^{15} \mathrm{~N}\right)$ obtained for pork samples of 14 countries are given in Table 1 . These can be clearly divided into 3 major groups, Europe, America and South Korea, on the basis of $\delta^{13} \mathrm{C}$ and $\delta^{15} \mathrm{~N}$ composition values as shown in Fig. 1.

\section{Stable isotope ratio values of carbon $\left(\delta^{13} \mathrm{C} \%\right)$}

As shown in Table 2, the $\delta^{13} \mathrm{C}$ values for the nine European countries studied ranged between $-27.17 \pm 0.52 \%$ (Finland) to $-23.44 \pm 1.09 \%$ (Spain). The values of $\delta^{13} \mathrm{C}$ in the same region were found very close for Netherland (-25.57 $\pm 1.20 \%$ ) and Denmark (-25.24 $\pm 0.22 \%$ ), Austria ( -24.20 $\pm 1.27 \%$ ), France $(-24.35 \pm 1.05 \%$ ), Belgium $(-24.80 \pm 1.33 \%$ ) and Poland $(-24.77 \pm 1.52 \%$ ) and Spain $(-23.44 \pm 1.09 \%$ ) and Hungry $(-23.78 \pm 1.48 \%$ ). Among the four countries of American region studied, the $\delta^{13} \mathrm{C}$ values for USA, Mexico, Chile and Canada were $-14.78 \pm 1.34 \%$, $-14.81 \pm$ $0.46 \%$ o, $-15.93 \pm 0.63 \%$, and $-22.87 \pm 0.92 \%$ respectively. The average $\delta^{13} \mathrm{C}$ value for 335 samples of South Korea was found to be $-19.62 \pm 0.89 \%$ (Table 1 and Fig. 1).

\section{Stable isotope ratio values of nitrogen $\left(\delta^{15} \mathrm{~N} \% \mathrm{o}\right)$}

The $\delta^{15} \mathrm{~N}$ values ranged between $3.69 \pm 0.54 \%$ o for South Korea to $5.73 \pm 0.31 \%$ for Finland. The countries of American region gave $5.65 \pm 0.53 \%$ and $5.42 \pm 0.58 \%$ or Canada and USA, while $4.81 \pm 0.56 \%$ and $4.72 \pm 0.67 \%$ for Mexico and Chile respectively. Among the European countries, the $\delta^{15} \mathrm{~N}$ values were $3.62 \pm 0.15 \%$ (Denmark), $4.42 \pm 0.51 \%$ (Austria), $4.42 \pm 0.58 \%$ (Hungry), $4.46 \pm 0.73 \%$ o (Belgium), 4.53 $\pm 0.85 \%$ o (Poland), 4.58 $\pm 0.47 \%$ o (Nether-

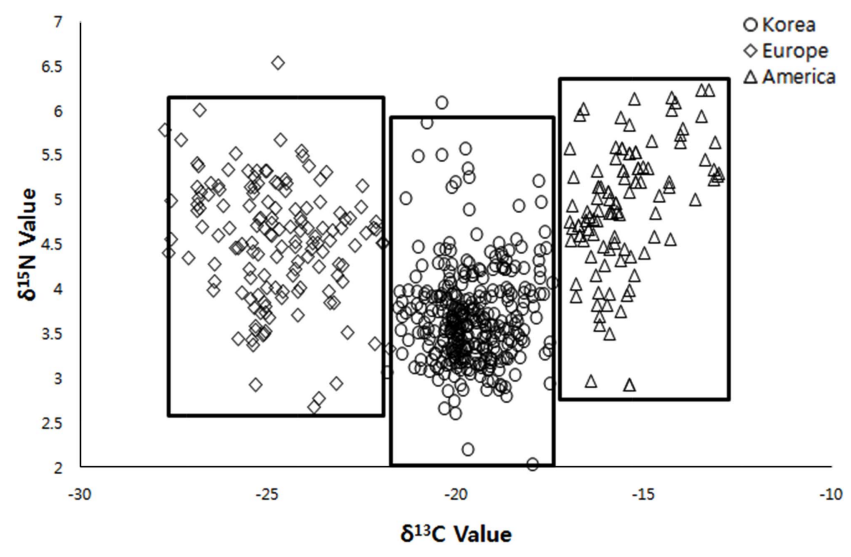

Fig. 1. Two dimension graphical analysis of stable isotope ratios carbon $\left(\delta^{13} \mathrm{C} \%\right.$ ) and nitrogen $\left(\delta^{15} \mathrm{~N} \%\right)$ of the pork defatted dry mass (DDM) protein from South Korea and other regions. 
land), $4.68 \pm 0.26 \%$ (Spain), 4.96 $\pm 0.50 \%$ (France), and $5.73 \pm 0.31 \%$ (Finland) (Table 1 and Fig. 1).

\section{Discussion}

Meat always proved to be quite a complex material for isotope analysis. Mostly the interpretation of results is very difficult for several reasons. The fodder is not often grown locally and therefore the link to local geology is not straightforward. Also different tissues of an animal have different turnover rates and it is quite possible to get various ratios within one sample. Additionally chemical composition of animal protein always makes the isotope analysis very difficult (Rummel et al., 2012).

To cope with these possible hurdles, samples were sourced through National Agricultural Products Quality Management Service, Republic of Korea. The samples were collected directly from the producers and therefore can be considered as authentic. Also within the muscle tissues of an animal, the isotopic ratios of carbon and nitrogen should not differ significantly. The results obtained for both $\delta^{13} \mathrm{C} \%$ and $\delta^{15} \mathrm{~N} \%$ are evaluated separately as follow.

\section{Evaluation of pork meat defatted dry mass (DDM) $\delta^{13} \mathrm{C} \%$ measurements}

It is well known that stable isotopes of carbon $\left({ }^{12} \mathrm{C}\right.$ and ${ }^{13} \mathrm{C}$ ) in food animals is dependent upon the type of food they take, which is directly related to geographical location of the country (Camin et al., 2004). In those areas of the world where animals are fed with more photosynthetic food $\left(\mathrm{C}_{3}\right.$ plant materials), rich in ${ }^{12} \mathrm{C}$ isotope, their bodies are loaded with more ${ }^{12} \mathrm{C}$ isotope than ${ }^{13} \mathrm{C}$ and therefore when analyzed will have low stable isotope ratio value of carbon $\left(\delta^{13} \mathrm{C} \%\right)$.

On the other hand, animals fed on non-photosynthetic foods like grains $\left(\mathrm{C}_{4}\right.$ plant materials), have comparatively high ${ }^{13} \mathrm{C}$ content and therefore will show high stable isotope ratio value of carbon $\left(\delta^{13} \mathrm{C} \%\right.$ ) (Schewertl et al., 2005). Studies on cattle tissues such as hairs (Minson et al., 1975), dairy products like milk (Kornexl et al., 1997), butter (Rossenmann et al., 2000) and cheese (Camin et al., 2004) confirms that $\delta^{13} \mathrm{C} \%$ value is dependent upon the proportion of $\mathrm{C}_{3}$ and $\mathrm{C}_{4}$ plant materials in the diet of animal, prior to slaughter. It has been demonstrated that in beef samples when the cattle is exposed to $\mathrm{C}_{4}$-maize silage feedings for prolonged periods, in excess of 12 mon, high $\delta^{13} \mathrm{C} \%$ is obtained (Bahar, 2006; Boner and Forstel, 2004).
The feeding plant materials to animals cannot be the same in different regions of the world, as each part has unique climatic conditions and thus samples from different geological locations will have specific $\delta^{13} \mathrm{C} \%$, which can be used for origin authentication. According to the results given in Table 1, a clear distinction can be made while looking to the $\delta^{13} \mathrm{C} \%$ values of different countries.

\section{Evaluation of pork meat defatted dry mass (DDM) $\delta^{15} \mathrm{~N} \%$ measurements}

Stable isotopes of nitrogen $\left({ }^{14} \mathrm{~N}\right.$ and $\left.{ }^{15} \mathrm{~N}\right)$ in the food animals depend upon the atmosphere, types of plants, climatic conditions and soil texture of region where they grown up. It has been demonstrated in the past that if same animals are feed the same food but in different regions having different climatic conditions, the $\delta^{15} \mathrm{~N} \%$ values will be different (Kornexl et al., 1997; Piasentier et al., 2003). Therefore $\delta^{13} \mathrm{C} \%$ values always do not give any clear picture for origin authentication, especially when the feeding habits are only slightly different. For such cases the $\delta^{15} \mathrm{~N} \%$ evaluation is very fruitful to confirm the origin authentication, as both carbon and nitrogen are the important components of organic matters (Ghidini et al., 2006).

Stable isotope ratio measurements of nitrogen $\left(\delta^{15} \mathrm{~N} \%\right.$ ), for the defatted dry mass (DDM) of 599 pork samples from 14 countries studied, are given in Table 1, and shown in Fig. 1. It can be noted that there is slight variation among the $\delta^{15} \mathrm{~N} \%$ values for countries of Europe and American regions. For Korean samples the $\delta^{15} \mathrm{~N} \%$ value obtained was $3.69 \pm 0.54 \%$, which is adding the authentication of Korean pork from Europe and America regions. For American region, the $\delta^{15} \mathrm{~N} \%$ values of Canada $(5.65 \pm 0.53 \%$ ) and USA, $(5.42 \pm 0.58 \%$ ) are very close and slightly different from Mexico $(4.81 \pm 0.56 \%)$ and Chile $(4.72 \pm 0.67 \%$ ).

This slight variation in the same region may be due to the difference in their atmosphere, soil fertility, plants nature and over all climatic conditions. It can be noted here that the $\delta^{13} \mathrm{C} \%$ value for Canada was very low among the countries of American region and was making confusions about origin authentication, as discussed above. Now after evaluating the $\delta^{15} \mathrm{~N} \%$, the said confusion is solved. This lead us to suggest that both $\delta^{13} \mathrm{C} \%$ and $\delta^{15} \mathrm{~N} \%$ values were required for clear picture of origin authentication.

From the nine European countries studied, the $\delta^{15} \mathrm{~N} \%$ values for seven ranged between $4.42 \pm 0.51 \%$ o to $4.96 \pm$ $0.50 \%$. This shows their similar climatic conditions and soil fertility, being in the same group. The $\delta^{15} \mathrm{~N} \%$ for Denmark was found the lowest $(3.62 \pm 0.15 \%$ ), within the 
statistical probability variation calculated $(p<0.05)$ indicating difference from other countries of the same group and relatively close to South Korea. Finland showed 5.73 $\pm 0.31 \%$, comparable to Canada and USA.

\section{Conclusions}

A total of 599 pork samples from South Korea and 13 countries of America and Europe were analyzed for stable isotope ratios of carbon $\left(\delta^{13} \mathrm{C} \% \mathrm{)}\right)$ and nitrogen $\left(\delta^{15} \mathrm{~N} \%{ }\right)$, using Elemental Analyzer Isotope Ratio Mass Spectrometer (EA-IR/MS). Results showed significant variation, related to the origin of samples, due to the difference in feeding styles of pork in each country. On the whole stable isotope ratio study gave enough information and hence found a potential tool for origin authentication. Values of carbon $\left(\delta^{13} \mathrm{C} \%\right.$ ) and nitrogen $\left(\delta^{15} \mathrm{~N} \% \mathrm{~s}\right)$ for samples from South Korea were found in between the American region and Europe, explaining its specific regional feature. Thus pork of South Korea can be distinguished in the local market from other internationally supplied ones by the application of stable isotope ratios of carbon and nitrogen.

\section{Acknowledgement}

This study was supported by the Ministry of Agriculture and Forestry, Republic of Korea, research project (308021-03-3-HD120, 2011).

\section{References}

1. Anklam, E. (1998) A review of the analytical methods to determine the geographical and botanical origin of honey. Food Chem. 63, 549-562.

2. Bahar, B. (2006) Development of isotopic and molecular techniques for the authentication of dietary background information in bovine tissues. Ph.D. thesis, Univ., College Dublin, pp. 77.

3. Balling, H. P. and Rossmann, A. (2004) Countering fraud via isotope analysis-Case report. Kriminalistik. 58, 44-47.

4. Boner, M. and Forstel, H. (2004) Stable isotope variation as a tool to trace the authenticity of beef. Anal. Bioanal. Chem. 378, 301-310.

5. Camin, F., Bontempo, L., Heinrich, K., Horacek, M., Kelly, S. D., Schlicht, C., Thomas, F., Monahan, F. J., Hoogewerff, J., and Rossmann. A. (2007). Multi-element (H,C,N,S) stable isotope characteristics of lamb meat from different European regions. Anal. Bional. Chem. 389, 309-320.

6. Camin, F., Wietzerbin, K., Blanch Cortes, A., Haberhauer, G., Lees, M., and Versini, G. (2004) Application of multielement stable isotope ratio analysis to the characterization of
French, Italian, and Spanish cheeses. J. Agric. Food Chem. 52, 6592-6601.

7. Choi, B. A., Lee, H. K., Jeon, G. J., Oh, J. D., Choi, I. S., Park, M. H., Kong, H. S., Jung, I. J., Kim, T. H., Yoon, D. H., and Cho, B. W. (2004) Application of DNA Test for Undicidual Traceability in the Brand Marketing of Korean Native Pig. Korean J. Org. Agric. 12, 197-207.

8. Choy, E. J., Richard, P., Kim, R. K., Kang, C. K. (2009) Quantifying the trophic base for benthic secondary production in the Nakdong River estuary of Korea, using stable C and $\mathrm{N}$ isotopes. J. Exp. Mar. Biol. Ecol. 382, 18-26.

9. Day, M. P., Zhang, G., and Martin, G. J. (1995) Determination of the geographical origin of wine using joint analysis of elemental and isotopic composition. II- Differentiation of the principal production zones in France for the 1990 vintage. $J$. Sci. Food Agric. 67, 113-123

10. EEC (1992) European Economic Community Council Regulation No 2081/92, on the protection of geographical indications and designations of origin for agricultural products and foodstuffs. Available online at: http://eur-lex.europa.eu/LexUriServ/LexUriServ.do?uri=CONSLEG:1992R2081:20040501: EN:PDF

11. Ghidini, S., Ianieri, A., Zanardi, E., Conter, M., Boschetti, T., Iacumin, P., and Bracchi, P. G. (2006) Stable isotopes determination in food authentication: a review. Ann. Fac. Medic. Vet. Di Parma. 26, 193-204.

12. Hargin, K. D. (1996) Authenticity issues in meat and meat products. Meat Sci. 43, 277-289.

13. Hegerding, L., Seidler, D., Danneel, H. J., Gessler, A., and Nowak, B. (2002) Oxygen isotope-ratio-analysis for the determination of the origin of beef. Fleischwirtschaft 82, 95-100.

14. Jardine, T. D., McGeachy, S. A., Paton, C. M., Savoie, M., and Cunjak, R. A. (2003) Analysis and interpretation. Canadian Manuscript Report of Stable isotopes in aquatic systems: sample preparation, No 2656. Fisheries and Aquatic Sciences. Canada. Available online at: http://www.dfo-mpo. gc.ca/libraries-bibliotheques/manu-eng.htm

15. Jeong, M. S. and Lee, S. B. (2008) Discrimination of geographical origin for herbal medicine by mineral content analysis with energy dispersive x-ray fluorescence spectrometer. Korean J. Food Sci. Technol. 40, 135-140.

16. Kang, M. R., Lee, I. H., Hun, H., Kim, Y. S., and Lee, S. C., (2001) Elemental analysis in Astragali radix by using ICPAES and determination of the original agricultural place of oriental medicine by using a chemometrics. Anal. Sci. Technol. 14, 315-321.

17. Kim, E. Y., Kim, J. H., Lee, N. Y., Kim, S. J., and Rhyu, M. R. (2003) Discrimination of geographical origin for astragalus Root (Astragalus membranaceus) by capillary electrophoresis and near-infrared spectroscopy. Korean J. Food Sci. Technol. 35, 818-824.

18. Kim, M. H., Rho, H. H., and Lee, C. H. (2009) The geographical discrimination of Korean and Chinese soybeans (Glycine max (L.) merrill) using NMR relaxation methods. Korean J. Food Sci. Technol. 41, 292-295.

19. Kornexl, B. E., Werner, R., and Rossmann, A. (1997) Mea- 
surement of stable isotope abundances in milk and milk ingredients - A possible tool for origin assignment and quality control. Eur. Food Res. Technol. 20, 19-24.

20. Lee, N. Y., Bae H. R., and Noh B. S. (2006) Discrimination of geographical origin of Mushroom (Tricholoma matsutake) using near infrared spectroscopy. Korean J. Food Sci. Technol. 386, 835-837.

21. Lim, C. L., Son, H. J., Hong, E. J., and Noh, B. S. (2008) Discrimination of geographical origin of beef using electronic nose based on mass spectrometer. Korean J. Food Sci. Technol. 40, 717-720.

22. Minson, D. J., Ludlow, M. M., and Troughton, J. H. (1975) Differences in natural carbon isotope ratios of milk and hair from cattle grazing tropical and temperate pastures. Nature 256, 602-602.

23. Peterson, B. J. and Fry, B. (1987) Stable isotopes in ecosystem studies. Annu. Rev. Ecol. Syst. 18, 293-320.

24. Piasentier, E., Valusso, R., Camin, F., and Versini, G. (2003) Stable isotope ratio analysis for authentication of lamb meat. Meat Sci. 64, 239-247.

25. Renou, J. P., Bielicki, G., Deponge, C., Gachon, P., Micol, D., and Ritz, P. (2004) Characterization of animal products according to geographic origin and feeding diet using nuclear magnetic resonance and isotope ratio mass spectrometry. Part II: Beef meat. Food Chem. 86, 251-256.
26. Rossmann, A., Haberhauer, G., Holzl, S., Horn, P., Pichlmayer, F., and Voerkelius, S. (2000) The potential of multielement stable isotope analysis for regional origin assignment of butter. Eur. Food Res. Technol. 211, 32-40.

27. Rummel, S., Dekant, C. H., Holzl, S., Kelly, S. D., Baxter, M., Marigheto, N., Quetel, C. R., Larcher, R., Nicolini, G., Froschl, H., Ueckermann, H., and Hoogewerff. J. (2012) Sr isotope measurements in beef-analytical challenge and first results. Anal. Bioanal. Chem. 402, 2837-2848.

28. Schwertl, M., Auerswald, K., Schaufele, R., and Schnyder, H. (2005) Carbon and nitrogen stable isotope composition of cattle hair: ecological fingerprints of production systems? Agric. Ecosyst. Environ. 109, 153-165.

29. Simon, K., Karl, H., and Jurian, H. (2005) Tracing the geographical origin of food: The application of multi-element and multi-isotope analysis. Trends Food Sci. Tech. 16, 555567.

30. Yuta, Y., Hirooka, H., Oishi, K., Choumei, Y., Hata, H., Arai, H., Kitagawa, M., Gotoh, T., Inada, S., and Kumagai, H. (2012) Stable carbon and nitrogen isotope analysis as a tool for inferring beef cattle feeding systems in Japan. Food Chem. 134, 502-506.

(Received 2012.8.1/Revised 2012.12.13/Accepted 2013.1.4) 